Saudi Journal of Business and Management Studies Abbreviated Key Title: Saudi J Bus Manag Stud ISSN 2415-6663 (Print) IISSN 2415-6671 (Online) Scholars Middle East Publishers, Dubai, United Arab Emirates Journal homepage: https://saudijournals.com/sibms

Original Research Article

\title{
Effects of Customer Satisfaction on Customer Loyalty in Selected Hotels in Nairobi, Kenya
}

\author{
Lydia Akunja*
}

School of Tourism, Hospitality and Events Management, Moi University P.O Box 3900-30100, Eldoret, Kenya

DOI: $10.36348 /$ sjbms.2020.v05i06.004

| Received: 25.05.2020 | Accepted: 02.06.2020 | Published: 17.06.2020

*Corresponding author: Lydia Akunja

\section{Abstract}

Customer loyalty is a key objective for organizations pursuing a relationship approach with their customers. Creating and maintaining loyalty with customers is critical for the survival of a company in a competitive environment as in the hospitality sector. The link between customer satisfaction and customer loyalty in the service sector especially in hotels seems to be unclear. Further, limited literature and studies related to customer satisfaction and customer loyalty exist in the hotel sector in Kenya, hence the need for this study. The purpose of this study was to provide an understanding of the effects of customer satisfaction on customer loyalty in the hotel sector in Kenya. The sample size for the study was 253 and six marketing managers who were used as key informers. The study employed purposive, stratified and systematic random sampling. Reliability was tested using Cronbach's Alpha resulting in a value 0.924 . Factor analysis was used for data reduction while simple regression was used to analyze and test the hypothesis. The findings of this study indicated that customer satisfaction ( $\mathrm{t}=13.940, \mathrm{p}<.001)$ significantly affected customer loyalty. It was concluded that an improvement in customer satisfaction would likely result into improved customer loyalty.

Keywords: Customer, loyalty, satisfaction, hospitality sector.

Copyright @ 2020: This is an open-access article distributed under the terms of the Creative Commons Attribution license which permits unrestricted use, distribution, and reproduction in any medium for non-commercial use (NonCommercial, or CC-BY-NC) provided the original author and source are credited.

\section{INTRODUCTION}

The hotel industry has become very competitive and is considered to be in the mature stage of its lifecycle. The link between customer satisfaction and customer loyalty is neither straightforward nor simple and neither is its effect on customer loyalty especially in the Kenyan context. The purpose of this study was to examine the effects of customer satisfaction on customer loyalty in the hotel industry. The study sought to make recommendations on measures hospitality practitioners can employ in developing customer loyalty. It was expected that customer loyalty would have a positive impact on organizational performance in terms of gaining a competitive advantage.

\section{RESEARCH HYPOTHESES}

$\mathrm{Ho}_{1}$ Customer satisfaction does not have significant effects on customer loyalty

\section{LITERATURE REVIEW}

Loyalty in service markets is defined as a dimensional concept since any given customer may exhibit different degrees of loyalty to a service provider. Customers may be highly loyal on one dimension, while at the same time exhibit low loyalty on other dimensions. A loyal customer is one who: makes regular purchases, purchases across product and service lines refers others and demonstrates immunity to the pull of the competition [1]. Customer loyalty is a deeply held commitment to rebuy or repatronise a preferred product or service consistently in the future, despite situational influences and marketing efforts having the potential to cause switching behavior Oliver [2]. Customer loyalty is a key objective for organizations pursuing a relationship approach with their customers. According to Prus and Brandt [3], loyal customers repeatedly purchase products or services, they recommend a company to others and they stick with a business over time. Loyal customers stay with 
Lydia Akunja; Saudi J Bus Manag Stud, June, 2020; 5(6): 334-342

organizations longer, buy more from them and more often have increased lifetime value [4].

A loyal customer is a customer whose expectations are met or exceeded and they proactively refer the supplier. The nature of loyalty has changed over time in society; nowadays it is based on mutually earned loyalty by the continued delivery of superior value to the customer. Customer loyalty can be measured and analysed to minimise customer turnover and to increase the growth of key accounts. Griffin [5] defined a loyal customer as a customer who regularly repeat purchases, purchases across product and service lines, has some level of immunity to competitors, and refers to others [6-11].

Reichheld and Sasser [12] found that a 5\% increase in customer retention resulted in a $25-125 \%$ increase in profits. This increase in profit is due to lower sales and marketing costs, increased price premiums, referrals and revenue growth [13-17]. Further, loyal consumers have fewer reasons to engage in an extended information search among alternatives, thus reducing the probability of switching to other brands [18]. Still, based on their research in luxury hotel, Bowen and Shoemaker [19] stated that loyal customers claimed that they purchased other hotel services (like laundry and restaurant meals) more frequently at hotels towards which they felt loyal compared to hotels where there was little loyalty.

Customer satisfaction is one of the objectives of marketing activity [20], linking the process of purchasing and consumption with post purchase phenomena. Satisfying customers is an important element in marketing concept [21] as it affects future consumer purchase behaviour [22-24], profitability [25, 26], and shareholder value [27]. There are many definitions given to the term customer satisfaction with an early one given stresses on cognitive process [28]. More recently, consumer satisfaction paradigm research has gone beyond cognitively toned formulations to recognize the affective nature of satisfaction with Tse and Wilton [29] defining it as consumer's response to the evaluation of the perceived discrepancy between prior expectation and the actual performance of the product as perceived after its consumption. While other variations of the definition of customer satisfaction have been presented by scholars, most of the definitions agree that satisfaction is a complex human process, involving cognitive, affective and other undiscovered psychological and physiological dynamics $[30,31]$.

Theories such as Expectation-Disconfirmation and Comparison-Level Theory attempt to explain customer satisfaction [22, 32]. Expectancy Disconfirmation Theory is arguably the most influential and has received the widest acceptance [33, 34]. Expectancy-Disconfirmation Theory examines the formation of expectations and the disconfirmation of those expectations through performance comparison. Expectations reflect a pre-consumption perception associated with goods and services, whereas performance is the basis of the customer's perception of goods and services [20, 35]. Disconfirmation arises from the discrepancy between prior expectation and actual performance of goods and services. This disconfirmation concept occupies a central position as a crucial intervening variable in the Expectancy Disconfirmation paradigm [36]. If a customer perceives the quality of the product or service that they buy exceeds their needs, wants, and expectations, customer satisfaction will be high (positive disconfirmation). Alternatively, if a customer perceives that the quality of the product or service does not meet their needs, wants, and expectations, then, customer satisfaction will be low (negative disconfirmation).

Work done by Parasuraman, Zeithaml and Berry between 1985 and 1988 provides the basis for the measurement of customer satisfaction with a service by using the gap between the customer's expectation of performance and their perceived experience of performance. This provides the measurer with a satisfaction "gap" which is objective and quantitative in nature. Work done by Cronin and Taylor propose the "confirmation/disconfirmation" theory of combining the "gap" described by Parasuraman [37], Zeithaml and Berry [38] as two different measures (perception and expectation of performance) into a single measurement of performance according to expectation. Companies are supposed to be accurate and dependable to provide the service they promised. Customer service expectations have two levels: the desired service level that is the service the customer hopes to receive and the adequate service level that which customer find acceptable [37]. A key approach to managing expectations is to manage the promises. Firms will have a better chance of meeting customer expectations when their promises reflect the service actually delivered rather than an idealized version of the service. They further dispute either under promising or overpromising. Service firms seeking to exceed customer expectations in order to enhance their quality image should capitalize on the best opportunity for doing so.

Customers' desires for more personalized and closer relationships with service providers are evident not only in the interview transcripts for insurance and leasing services, which are ongoing by nature, but also for hotel and repair services, which are provided intermittently. Customer relationships are central to exceeding customer expectations. This is because relationship building is process-intensive, requiring responsive, assured, empathetic service over time [37]. Leveraging the process dimensions is critical when service failure occur. Communications between company and customers should be company-initiated as well as customer initiated. Service providers must have 
Lydia Akunja; Saudi J Bus Manag Stud, June, 2020; 5(6): 334-342

the means to efficiently tailor the service to customers' specific requirements, to at least some degree. In addition to being able to tailor service to customers, service providers must also be willing to do so [39].

However, scholars such as Oliver [40], Ganesh et al., [41], Harris and Goode [42], and Chandrashekaran et al., [43] maintain that previous research is still unable to convincingly explain the complex relationship between customer satisfaction and customer relations. This further enabled the testing of the hypotheses that customer satisfaction does not have effects on customer loyalty.

\section{MATERIALS AND METHODS}

The study was undertaken in Nairobi using explanatory research design. The main target unit for analysis were customers of six selected five-star hotels in Nairobi. The study had a sample size of 251 respondents and employed purposive, stratified and systematic random sampling. Purposive sampling was used to select six hotels out of seventeen five-star rated hotels in Nairobi, while systematic random sampling was used to select the respondents. Reliability was measured using the Cronbach's Alpha at a level of $0.7 \%$. Data analyzed using SPSS version 17.0. Simple regression was conducted to check the effects of the independent variable customer satisfaction against the dependent variable (customer loyalty). The regression model was given as:

$$
\mathrm{Y}_{\mathrm{i}}=\beta_{0+} \beta_{\mathrm{i}} \mathrm{X}_{\mathrm{i}}+\mu
$$

Where,

$$
\begin{aligned}
& Y_{i}=\text { Customer loyalty } \\
& X_{i=\text { Customer satisfaction }(C S)} \\
& \beta_{0}=\text { Constant term } \\
& \beta_{i}=\text { Regression coefficients } \\
& \mu=\text { Error term }
\end{aligned}
$$

The above model was estimated for $\mathrm{Y}$ against each of the independent variables.

\section{RESULTS AND DISCUSSION Customer Satisfaction (CS)}

In conducting the study, the researchers sought to establish the effect of customer satisfaction on customer loyalty. Based on the measures of customer satisfaction indicated in Table-1 it shows that the

\begin{tabular}{|c|c|c|c|c|c|c|c|c|c|c|c|c|}
\hline & \multicolumn{10}{|c|}{ Measurement } & \multirow{3}{*}{$\begin{array}{l}\text { Statistics } \\
\mathrm{M} \\
\end{array}$} & \\
\hline & \multicolumn{2}{|c|}{$\begin{array}{l}\text { Strongly } \\
\text { Disagree } \\
\text { (1) }\end{array}$} & \multicolumn{2}{|c|}{$\begin{array}{l}\text { Disagree } \\
\text { (2) }\end{array}$} & \multicolumn{2}{|c|}{$\begin{array}{l}\text { Neutral } \\
\text { (3) }\end{array}$} & \multicolumn{2}{|c|}{$\begin{array}{l}\text { Agree } \\
\text { (4) }\end{array}$} & \multicolumn{2}{|c|}{$\begin{array}{l}\text { Strongly } \\
\text { Agree } \\
(5)\end{array}$} & & \\
\hline & $f$ & $\%$ & $f$ & $\%$ & $f$ & $\%$ & $f$ & $\%$ & $f$ & $\%$ & & SD \\
\hline I have a pleasurable stay at the hotel & - & - & 1 & 0.5 & 22 & 12.0 & 31 & 16.9 & 129 & 70.5 & 4.574 & 0.722 \\
\hline $\begin{array}{l}\text { I did the right thing when choosing to stay } \\
\text { at the hotel }\end{array}$ & - & - & - & - & 18 & 9.8 & 42 & 23.0 & 123 & 67.2 & 4.574 & 0.666 \\
\hline $\begin{array}{l}\text { I feel the hotel services are better than my } \\
\text { expectations }\end{array}$ & 1 & 5 & 1 & 0.5 & 22 & 12.0 & 79 & 43.2 & 80 & 43.7 & 4.290 & 0.740 \\
\hline $\begin{array}{l}\text { I stay at this hotel more frequently than at } \\
\text { any other establishment }\end{array}$ & 32 & 17.5 & 11 & 6.0 & 14 & 7.7 & 43 & 23.5 & 83 & 45.4 & 3.732 & 1.512 \\
\hline $\begin{array}{l}\text { This hotel has a good first and last } \\
\text { impression }\end{array}$ & - & - & - & - & 12 & 6.6 & 46 & 25.1 & 125 & 68.3 & 4.618 & 0.608 \\
\hline The hotel allows for customer feedback & - & - & - & - & 13 & 7.1 & 42 & 23.0 & 128 & 69.9 & 4.628 & 0.615 \\
\hline $\begin{array}{l}\text { The interaction between senior staff and } \\
\text { guests influence my satisfaction }\end{array}$ & - & - & - & - & 17 & 9.3 & 70 & 38.3 & 96 & 52.5 & 4.432 & 0.658 \\
\hline $\begin{array}{l}\text { Overall, I am satisfied with my decision to } \\
\text { stay at the hotel }\end{array}$ & - & - & - & - & 11 & 6.0 & 43 & 23.5 & 129 & 70.5 & 4.645 & 0.593 \\
\hline
\end{tabular}
measures of customer satisfaction were found to be major determinants of customer loyalty with the mean statistics of between 3.7 and 4.6 and standard deviation of between 0.59 and 1.51 .

Table-1: Measures of Customer Satisfaction

Source: Survey Data,(2020)

\section{Customer Loyalty (CL)}

The respondents were asked to rate their feelings concerning a range of statements in relation to customer loyalty (CL). The attributes were analyzed on a 5-point Likert scale to establish the level of agreement. Table- 2 shows that all the measures of CL attained a mean statistic of between 4.0 and 4.5 with standard deviations of between 0.07 and 1.07. This could imply that the measures of CL were significant as majority of the responses were skewed towards anchor 4 (agreed) based on the means. 
Lydia Akunja; Saudi J Bus Manag Stud, June, 2020; 5(6): 334-342

Table-2: Measures of Customer Loyalty

\begin{tabular}{|c|c|c|c|c|c|c|c|c|c|c|c|c|}
\hline & \multicolumn{9}{|c|}{ Measurement } & & \multicolumn{2}{|c|}{ Statistics } \\
\hline & \multicolumn{2}{|c|}{$\begin{array}{l}\text { Strongly Disagree } \\
\text { (1) }\end{array}$} & \multicolumn{2}{|c|}{$\begin{array}{l}\text { Disagree } \\
(2)\end{array}$} & \multicolumn{2}{|c|}{$\begin{array}{l}\text { Neutral } \\
\text { (3) }\end{array}$} & \multicolumn{2}{|c|}{$\begin{array}{l}\text { Agree } \\
(4)\end{array}$} & \multirow{2}{*}{$\begin{array}{l}\text { Strongly } \\
\text { Agree } \\
(5) \\
f\end{array}$} & & & \\
\hline & $f$ & $\%$ & $f$ & $\%$ & $f$ & $\%$ & $f$ & $\%$ & & $\%$ & M & SD \\
\hline $\begin{array}{l}\text { I engage in repeat purchase at } \\
\text { the hotel }\end{array}$ & - & - & 1 & 0.5 & 30 & 16.4 & 48 & 26.2 & 104 & 56.8 & 4.393 & 0.776 \\
\hline $\begin{array}{l}\text { I purchase across product and } \\
\text { service lines }\end{array}$ & 4 & 2.2 & - & - & 42 & 23.0 & 64 & 35.0 & 73 & 39.9 & 4.104 & 0.905 \\
\hline $\begin{array}{l}\text { I am immune to the pull of the } \\
\text { hotel's competition }\end{array}$ & - & - & 9 & 4.9 & 32 & 17.5 & 68 & 37.2 & 74 & 40.4 & 4.131 & 0.873 \\
\hline $\begin{array}{l}\text { I would recommend this hotel } \\
\text { to someone else }\end{array}$ & 5 & 2.7 & - & - & 13 & 7.1 & 61 & 33.3 & 104 & 56.8 & 4.415 & 0.847 \\
\hline I stick with the hotel over time & 1 & 0.5 & 5 & 2.7 & 38 & 20.8 & 50 & 27.3 & 89 & 48.6 & 4.208 & 0.902 \\
\hline $\begin{array}{l}\text { I am committed towards the } \\
\text { services of the hotel }\end{array}$ & - & - & 5 & 2.7 & 15 & 8.2 & 44 & 24.0 & 119 & 65.0 & 4.514 & 0.762 \\
\hline $\begin{array}{l}\text { I exhibit total trust towards this } \\
\text { hotel }\end{array}$ & 1 & 0.5 & 10 & 5.5 & 25 & 13.7 & 73 & 39.9 & 74 & 40.4 & 4.142 & 0.890 \\
\hline $\begin{array}{l}\text { Benefits I get from the hotel } \\
\text { influence my repeat choice to } \\
\text { stay at the hotel }\end{array}$ & - & - & - & - & 29 & 15.8 & 43 & 23.5 & 111 & 60.7 & 4.448 & 0.753 \\
\hline $\begin{array}{l}\text { I would consider staying at this } \\
\text { hotel in future }\end{array}$ & - & - & - & - & 12 & 6.6 & 56 & 30.6 & 115 & 62.8 & 4.563 & 0.616 \\
\hline $\begin{array}{l}\text { I spend more money here } \\
\text { compared to other hotels }\end{array}$ & - & - & 28 & 15.3 & 6 & 3.3 & 51 & 27.9 & 98 & 53.6 & 4.197 & 1.071 \\
\hline $\begin{array}{l}\text { If the hotel were to raise the } \\
\text { rates, I would still stay in this } \\
\text { hotel }\end{array}$ & 1 & 0.5 & 15 & 8.2 & 32 & 17.5 & 62 & 33.9 & 73 & 39.9 & 4.044 & 0.977 \\
\hline $\begin{array}{l}\text { When I visit Nairobi I always } \\
\text { stay in this hotel }\end{array}$ & 2 & 1.1 & - & - & 25 & 13.7 & 64 & 35.0 & 92 & 50.3 & 4.333 & 0.794 \\
\hline
\end{tabular}

Source: Survey Data, (2020)

\section{Reliability Tests}

Cronbach's alpha was used to test the reliability of the data collected. These results showed that the indicators used to measure the variables were reliable in explaining the variables under study because they were all above the 0.7 threshold. The independent variable for the study was customer satisfaction. Customer satisfaction denoted as $\mathrm{X}_{1}$ with eight indicators had a Cronbach Alpha of 0.924 while the dependent variable Customer Loyalty (Y) with twelve indicators had a Cronbach Alpha of 0.926.

\section{Factor Analysis}

Factor analysis was carried out for each of the variables to reduce the number of items on each of the variables for ease of presentation, analysis, interpretation and discussion of the most significant factors.

Customer satisfaction was captured through statements on a 5- point likert scale. The KMO measure of sampling accuracy indicates a $\mathrm{KMO}=.778$ which is above the minimum 0.5 . This implies the sample size was adequate for the variables entered into analysis. Bartlett's Test of Sphericity that was used to test the adequacy of the correlation matrix yielded a value of 1117.315 and an associated level of significance smaller than 0.001 , therefore the findings implies that the factor analysis was appropriate for the study.

Table-3: KMO and Bartlett's Test of Customer Satisfaction
\begin{tabular}{|l|l|l|}
\hline Kaiser-Meyer-Olkin Measure of Sampling Adequacy. & $\mathbf{. 7 7 8}$ \\
\hline Bartlett's Test of Sphericity & Approx. Chi-Square & 1117.315 \\
\hline & Df & 28 \\
\hline & Sig. & .000 \\
\hline
\end{tabular}

Source: Survey Data, 2020

For customer satisfaction, eight factors were computed, but not all the factors were useful in representing the list of variables. Using the criterion of retaining only factors with eigen values of 1 or greater, the first 2 factors were retained for rotation. These 2 factors accounted for $59.23 \%$ and $13.66 \%$ of the total variance respectively. This is a $72.895 \%$ of the total variance attributed to the factors. The remaining factors account for $27.11 \%$ of the variance. Thus, a model with two factors may be adequate to represent the data. 
Table-4: Total Variance Explained of Customer Satisfaction

\begin{tabular}{|l|l|l|l|l|l|l|l|l|l|}
\hline Component & \multicolumn{3}{|l|}{ Initial Eigen values } & \multicolumn{2}{l|}{$\begin{array}{l}\text { Extraction Sums of Squared } \\
\text { Loadings }\end{array}$} & \multicolumn{2}{l|}{$\begin{array}{l}\text { Rotation Sums of Squared } \\
\text { Loadings }\end{array}$} \\
\hline & Total & $\begin{array}{l}\% \text { of } \\
\text { Variance }\end{array}$ & $\begin{array}{l}\text { Cumulative } \\
\%\end{array}$ & Total & $\begin{array}{l}\% \text { of } \\
\text { Variance }\end{array}$ & $\begin{array}{l}\text { Cumulative } \\
\%\end{array}$ & Total & $\begin{array}{l}\% \text { of } \\
\text { Variance }\end{array}$ & $\begin{array}{l}\text { Cumulative } \\
\%\end{array}$ \\
\hline Met expectations & 4.739 & 59.233 & 59.233 & 4.739 & 59.233 & 59.233 & 3.347 & 41.831 & 41.831 \\
\hline Positive feedback & 1.093 & 13.663 & 72.895 & 1.093 & 13.663 & 72.895 & 2.485 & 31.064 & 72.895 \\
\hline
\end{tabular}

Extraction Method: Principal Component Analysis.

a. 2 components extracted

Source: Survey Data, (2020)

Table-5 shows the rotated component matrix that presents two factors after Varimax rotation. The clustering of the items in each factor and their wording offer the best clue as to the meaning of the factors. These two components explain a total of variables grouped into each of the two principal components namely: met expectations and positive feedback. The interactions converged in 3 iterations. The components were rotated using Varimax Criterion to reduce the multi-collinearity and hence account for $100 \%$ of the variance.

Table-5: Rotated Component Matrix (a) of Customer Satisfaction

\begin{tabular}{|l|l|l|}
\hline & Component \\
\hline & Met expectations & Positive feedback \\
\hline Right thing to stay at the hotel & .939 & \\
\hline Pleasurable stay & .900 & \\
\hline Services better than expectations & .760 & \\
\hline Hotel has a good impression & .704 & \\
\hline There is senior staff-guest interaction & & .898 \\
\hline Overall satisfied with stay & & .808 \\
\hline Frequently stay & & .602 \\
\hline Allows feedback from customers & & .589 \\
\hline
\end{tabular}

Extraction Method: Principal Component Analysis. Rotation Method: Varimax with Kaiser Normalization. a Rotation converged in 3 iterations.

Source: Survey Data, (2020)

Twelve items measured customer loyalty through five point Likert type questions. The KMO measure of sampling accuracy indicates a $\mathrm{KMO}=0.845$ which is above the minimum 0.5. This implies the sample size was adequate for the variables entered into analysis. Bartlett's Test of Sphericity that was used to test the adequacy of the correlation matrix yielded a value of 1858.856 and an associated level of significance smaller than 0.001 , therefore the findings implies that the factor analysis was appropriate for the and that there was relationship among the variables.

Table-6: KMO and Bartlett's Test of Customer Loyalty

\begin{tabular}{|l|l|l|}
\hline \multicolumn{2}{|l|}{ Kaiser-Meyer-Olkin Measure of Sampling Adequacy. } & $\mathbf{. 8 4 5}$ \\
\hline Bartlett's Test of Sphericity & Approx. Chi-Square & 1858.856 \\
\hline & Df & 66 \\
\hline & Sig. & .000 \\
\hline
\end{tabular}

Source: Survey Data, 2020

As illustrated in Table-7, the total variance explained presents the number of common factors compounded, the eigen values associated with these factors, the percentage of total variance accounted for by the each factor and the accumulative percentage of the total variance accounted for by the factors. Although twelve factors were computed, not all the factors were useful in representing the list of variables. Using the criterion of retaining only factors with eigen values of 1 or greater, the first 3 factors were retained for rotation. These 3 factors accounted for $56.91 \%, 10.88 \%$ and $9.33 \%$ of the total variance respectively. This is $77.11 \%$ of the total variance attributed to the three factors. The remaining factors together account for approximately $22.89 \%$ of the variance. Thus, a model with three factors may be adequate to represent the data. 
Table-7: Total Variance Explained of Customer Loyalty

\begin{tabular}{|l|l|l|l|l|l|l|l|l|l|}
\hline Component & \multicolumn{3}{|l|}{ Initial Eigen values } & \multicolumn{2}{l}{$\begin{array}{l}\text { Extraction Sums of Squared } \\
\text { Loadings }\end{array}$} & \multicolumn{2}{l|}{$\begin{array}{l}\text { Rotation Sums of Squared } \\
\text { Loadings }\end{array}$} \\
\hline & Total & $\begin{array}{l}\% \text { of } \\
\text { Variance }\end{array}$ & $\begin{array}{l}\text { Cumulative } \\
\%\end{array}$ & Total & $\begin{array}{l}\% \text { of } \\
\text { Variance }\end{array}$ & $\begin{array}{l}\text { Cumulative } \\
\%\end{array}$ & Total & $\begin{array}{l}\% \\
\text { of } \\
\text { Variance }\end{array}$ & $\begin{array}{l}\text { Cumulative } \\
\%\end{array}$ \\
\hline Patronize & 6.829 & 56.907 & 56.907 & 6.829 & 56.907 & 56.907 & 3.504 & 29.199 & 29.199 \\
\hline Commitment & 1.305 & 10.879 & 67.786 & 1.305 & 10.879 & 67.786 & 3.046 & 25.380 & 54.579 \\
\hline Re-purchase & 1.119 & 9.326 & 77.112 & 1.119 & 9.326 & 77.112 & 2.704 & 22.533 & 77.112 \\
\hline
\end{tabular}

Extraction Method: Principal Component Analysis.

a. 3 components extracted

Source: Survey Data, (2020)

Table- 8 shows the rotated component matrix that presents three factors after varimax rotation. The clustering of the items in each factor and their wording offer the best clue as to the meaning of the factors. These three components explain a total of variables grouped into each of the three principal components namely: patronize commitment and re-purchase.
The interactions converged in 7 iterations. The components were rotated using Varimax Criterion to reduce the multi-collinearity and hence account for $100 \%$ of the variance.

Table-8: Rotated Component Matrix (a) of Customer Loyalty

\begin{tabular}{|l|l|l|l|}
\hline \multicolumn{3}{|l|}{ Component } \\
\hline & Patronize & Commitment & Re-purchase \\
\hline Spend more money at the hotel & .826 & & \\
\hline Committed to services of the hotel & .821 & & \\
\hline Consider future stay at the hotel & .703 & & \\
\hline Benefits influence repeat choice of stay & .688 & & \\
\hline Always stay at the hotel if in Nairobi & .620 & & \\
\hline Recommend hotel to someone else & & .826 & \\
\hline Total trust towards the hotel & & .823 & \\
\hline Stick with the hotel over time & & .695 & \\
\hline Still stay even if higher rates were introduced & & .554 & \\
\hline $\begin{array}{l}\text { Purchase across product lines } \\
\text { Immune to pull of hotel's competition }\end{array}$ & & & .888 \\
Engage in repeat purchase & & & .800 \\
\hline
\end{tabular}

Extraction Method: Principal Component Analysis. Rotation Method: Varimax with Kaiser Normalization. Source: Survey Data, (2020)

\section{Simple Regression Analysis}

Customer loyalty, which was the dependent variable, was denoted as $\mathrm{Y}$ and was made up of three sub variables or indicators namely; patronize, commitment and re-purchase. These three indicators were summed up and averaged to obtain customer loyalty. The independent variable was Customer satisfaction $\left(\mathrm{X}_{1}\right)$. The sub independent variables averaged to derive customer satisfaction were met expectations and positive feedback. A regression analysis of $\mathrm{Y}$ (customer loyalty) against $\mathrm{X}_{1}$ (customer satisfaction), was done and the regression model was as follows:

$$
\begin{aligned}
& Y_{i}=\beta_{o}+\beta_{1} X_{1}+\mu \\
& Y_{i}=-402+1.030 X_{1}+\mu
\end{aligned}
$$

From the above model, it is clear that there exist a positive relationship between $\mathrm{Y}_{\mathrm{i}}$ (customer loyalty) and customer satisfaction $\left(\mathrm{X}_{1}\right)$, based on the positive coefficient of the variable; $\hat{\beta}=1.030$. $\hat{\beta}=1.030$ is the sample parameter estimate of the population parameter $\beta$. It shows that when customer satisfaction improves by one unit percentage, customer loyalty is enhanced by $103.0 \%$. It follows then that a unit improvement in customer satisfaction in terms of met expectations and positive feedback aspects will improve customer loyalty by $103.0 \%$ among the sampled customers of five star hotels in Nairobi. 
Table-9: Coefficients of $\mathrm{Y}$ on $\mathrm{X}_{1}$

\begin{tabular}{|l|l|l|l|l|l|l|l|l|l|l|l|l|l|}
\hline Model & & \multicolumn{2}{|l|}{$\begin{array}{l}\text { Unstandardized } \\
\text { Coefficients }\end{array}$} & $\begin{array}{l}\text { Standardized } \\
\text { Coefficients }\end{array}$ & $\mathbf{T}$ & \multicolumn{1}{|l|}{$\begin{array}{l}\text { Sig\% } \\
\text { Confidence } \\
\text { Interval for B }\end{array}$} & \multicolumn{2}{l|}{ Correlations } & $\begin{array}{l}\text { Collinearity } \\
\text { Statistics }\end{array}$ \\
\hline & & B & $\begin{array}{l}\text { Std. } \\
\text { Error }\end{array}$ & Beta & & & $\begin{array}{l}\text { Lower } \\
\text { Bound }\end{array}$ & $\begin{array}{l}\text { Upper } \\
\text { Bound }\end{array}$ & $\begin{array}{l}\text { Zero- } \\
\text { order }\end{array}$ & Partial & Part & $\begin{array}{l}\text { Toler } \\
\text { Ance }\end{array}$ & VIF \\
\hline 1 & (Constant) & -.402 & .338 & & -1.189 & .236 & -1.069 & .265 & & & & & \\
\hline & $\begin{array}{l}\text { CUSTOMER } \\
\text { SATISFACTION }\end{array}$ & 1.030 & .074 & .720 & 13.940 & .000 & .884 & 1.175 & .720 & .720 & .720 & 1.000 & 1.000 \\
\hline
\end{tabular}

a Dependent Variable: Customer Loyalty

Source: Data analysis, (2020).

The 95\% confidence interval for the estimation of $\beta$ ranged between 0.884 and 1.175 for the lower and upper bound respectively. The true population parameter would lie in this range on 95 occasions out of one hundred occasions this parameter is estimated. The standard error of the estimate stood at 0.074. This is a small value in relation to the regression coefficient which implies a reliable prediction of $\beta$. The standard error is the estimate of how much the regression coefficient will vary between samples of the same size taken from the same population; that is, if one was to take multiple samples of the same size from the same population and use them to calculate the regression equation, this would be an estimate of how much the regression coefficient would vary from sample to sample.

$\mathrm{H}_{01}$ : Customer satisfaction does not have significant effect on customer loyalty

The sample estimate $\hat{\beta} 1=1.030$ was found to be statistically significant at $1 \%$ level with 181 degrees of freedom with $t_{1}=13.940$. Clearly therefore, customer satisfaction is a significant determinant of customer loyalty among the sampled clientele.

With this result, we reject the hypothesis that customer satisfaction has no effect on customer loyalty in selected hotels in Nairobi. This is because the calculated value of $t_{3}=13.940$ was greater than the critical value of $t_{\alpha}=2.960$. From the results sown on table 4.30, there exists a positive correlation between customer loyalty and customer satisfaction. The correlation coefficient between customer loyalty and customer satisfaction was 0.720 . The positive sign of the correlation indicates that the two variables tend to move together in the same direction, that is, they tend to increase or decrease together. The coefficient was found to be statistically significant at the $1 \%$ level of significance.

\section{CONCLUSIONS AND RECOMMENDATIONS}

Factor analysis derived specific components that comprised of significant factors that determined the expected value of customer loyalty. The independent variable customer satisfaction $\left(\mathrm{X}_{1}\right)$ consisted of two sub components namely; met expectations and positive feedback. The correlation coefficient was 0.720 . The correlation coefficients of the variable in the study was positive. It was therefore concluded that customer satisfaction $\left(\mathrm{X}_{1}\right)$ was a significant determinant of customer loyalty. To enhance customer loyalty in a hospitality operation therefore, more emphasis needs to be put on improving customer satisfaction.

Customer satisfaction is one of the objectives of marketing activity [20], linking the process of purchasing and consumption with post purchase phenomena. Satisfying customers is an important element in marketing concept as suggested by Kotler \& Armstrong [21] as it affects future consumer purchase behaviour according to [22-24], profitability [25, 26], and shareholder value [27]. Majority of the customers had a pleasurable stay at the hotels where some guests described their stay as "pleasantly surprising", "exquisite, warm and relaxing". The customers considered their decision to stay at the hotel to be right as the hotels were able to meet their needs and expectations whether it was for leisure or business travelers. This goes a long way in influencing customers' future purchase decisions. These findings are consistent with Parasuraman et al., [37] who argue that companies are supposed to be accurate and dependable to provide the service they promised.

Guests felt the services they received were better than their expectations. This was rated highly by $87 \%$ the customers. They received variety in product offerings, effective problem resolution, and value for money and were overall pleasantly surprised with the hotel. In this study customers frequently stayed at the hotels but there were those who were either staying at the establishments for the first time or had been there not more that approximately thrice. Customers' desires for more personalized and closer relationships with service providers are evident not only in the interview transcripts for insurance and leasing services, which are ongoing by nature, but also for hotel and repair services, which are provided intermittently. Customer relationships are central to exceeding customer expectations. This is because relationship building is process-intensive, requiring responsive, assured, empathetic service over time [37]. The findings of this study support this statement as $68.3 \%$ of the customers agreed that the hotels allowed for customer feedback. Feedback allows management to incorporate all aspects relating to compliments, suggestions, comments and complaints. Whether formal or informal, it allows 
Lydia Akunja; Saudi J Bus Manag Stud, June, 2020; 5(6): 334-342

operators to know what their customers want in order to provide a customer focused experience. This is further supported by the responses of $90.8 \%$ who agreed that there was interaction between senior staff and guests which influenced their satisfaction. Overall, $70.5 \%$ of the customers indicated they were satisfied with their decision to stay at the hotel.

While other variations of the definition of customer satisfaction have been presented by scholars, most of the definitions agree that satisfaction is a complex human process, involving cognitive, affective and other undiscovered psychological and physiological dynamics [30, 31]. The findings of this study support this statement and signify a positive relationship between customer satisfaction and customer loyalty, hence a rejection of the hypothesis: Customer satisfaction does not have significant effect on customer loyalty.

An improvement in customer loyalty would likely result into improved customer loyalty. Customer satisfaction significantly affects customer loyalty. The perceived discrepancy between prior expectation and the actual performance of a service significantly determines customer loyalty. The regression results further indicated that customer satisfaction affected customer loyalty. Therefore there is need to promote factors that enhance customer loyalty and further look at other factors that could affect customer loyalty. Based on the findings from this study, the researcher recommends the following: Non monetary benefits should be offered to guests in order to influence repeat patronage while giving the hotels a competitive edge against their competitors, All members of staff should focus on meeting and exceeding guest expectations with the aim of satisfy them hence influencing their loyalty toward the hotel brands and Promoting staff-guest interactions is also crucial for any establishment seeking to remain relevant in a highly competitive environment.

\section{REFERENCES}

1. Griffin, J. (2002). Customer Loyalty: How to Earn It, How to Keep It, Lexington Books, New York, USA.

2. Oliver, R. L. (1997). Satisfaction: A behavioral perspective on the consumer New York: McGraw Hill.

3. Prus, A., Brandt, D. R. (1995). Understanding your customers. American Demographics, 10-13.

4. Stone, M. \& Woodcock, N., Relationship Marketing, Kogan Page, London.1995.

5. Griffin, F. J., \& Griffin, F. J. (1995). "Who Set You Flowin'?": The African-American Migration Narrative. Oxford University Press.

6. Gouillart, F., \& Sturdivant, F. D. (1994). Topmanager müssen den Wünschen der Kunden selbst nachspüren. Harvard Business Manager, 3(94), 32-40.
7. Hepworth, M., \& Mateus, P. (1994). Connecting customer loyalty to the bottom line. Canadian Business Review, 21, 40-40.

8. Wellington, S. L., Vinegar, H. J., \& Gipson, T. C. (1995). U.S. Patent No. 5,409,071. Washington, DC: U.S. Patent and Trademark Office.

9. Reichheld, F. F. (1996). The Loyalty Effect: The Hidden Eorce Behind Growth. Profits and Lasting Value. Boston: Harvard Business School Press.

10. Dickey, T., Frye, D., McNeil, J., Manov, D., Nelson, N., Sigurdson, D., ... \& Johnson, R. (1998). Upper-ocean temperature response to Hurricane Felix as measured by the Bermuda Testbed Mooring. Monthly Weather Review, 126(5), 1195-1201.

11. Gitomer, J. H. (1998). Customer Satisfaction is worthless, Customer loyalty is priceless: How to make customers love you, keep them coming back and tell everyone they know. Bard.

12. Reichheld, F. F., \& Sasser, W. E. (1990). Zero defections: Quality comes to services. Harvard Business Review, 68(5), 105-111.

13. Heskett, J. (2002). Beyond customer loyalty. Managing Service Quality, 12(6), 355-357.

14. McMullan, R., \& Gilmore, A. The conceptual development of customer loyalty measurement: A proposed scale. Journal of Targeting, Measurement and Analysis for Marketing, 11(3), 230-243. 2003

15. McMullan, R., \& Gilmore, A. (2008). Customer loyalty: An empirical study. European Journal of Marketing, 42(9/10), 1084-1094.

16. Reichheld, F. F. (2003). The one number you need to grow. Harvard Business Review, 81(12), 46-54.

17. Rowley, J. (2005). The four Cs of customer loyalty. Marketing Intelligence \& Planning, 23(6/7), 574-582.

18. Gounaris, S., \& Stathakopoulos, V. (2004). Antecedents and consequences of brand loyalty: An empirical study. Journal of Brand Management, 11, 283-306.

19. Bowen, J. T., \& Shoemaker, S. (2003). Loyalty: A strategic commitment. Cornell Hotel and Restaurant Administration Quarterly, 44(5/6), 3146.

20. Holbrook, M. B. (1994). The nature of customer value: An axiology of services in the consumption experience. In Rust, R. T., \& Oliver, R. L. (Eds.), Service quality: New direction on theory and practice: Sage Publications.

21. Kotler, P., \& Armstrong, G. (2004). Principles of marketing (Vol. 10th). Upper Saddle River, NJ Prentice Hall.

22. Yi, Y. (1990). A critical review of consumer satisfaction. Review of marketing, 4(1), 68-123.

23. Oh, H., \& Parks, S. C. (1997). Customer satisfaction and service quality: A critical review of the literature and research implications for the hospitality industry. Hospitality Research Journal, 20(3), 35-64. 
Lydia Akunja; Saudi J Bus Manag Stud, June, 2020; 5(6): 334-342

24. Yoo, D. K., \& Park, J. A. (2007). Perceived service quality - analyzing relationships among employees customers, and financial performance. International Journal of Quality \& Reliability Management, 24(9), 908-926.

25. Anderson, E. W., Fornell, C., \& Lehmann, D. R. (1994). Customer satisfaction, market share, and profitability: Findings from Sweden. Journal of Marketing, 58, 53-66.

26. Chitty, B., Ward, S., \& Chua, C. (2007). An application of the ECSI model as a predictor of satisfaction and loyalty for backpacker hostels. Marketing Intelligence \& Planning, 25, 563-580.

27. Anderson, E. W., Fornell, C., \& Mazvancheryl, S. K. (2004). Customer satisfaction and shareholder value. Journal of Marketing, 68(4), 172-185.

28. Howard, J. A., \& Sheth, J. N. (1969). The theory of buyer behavior. New York: Wiley.

29. Tse, D. K., \& Wilton, P. C. (1988). Models of consumer satisfaction formation: An extension. Journal of Marketing Research, 25(2), 204-212.

30. Woodruff, R. B. (1997). Customer value: The next source for competitive advantage. Academy of Marketing Science Journal, 25(2), 139-153.

31. Bhattacharya, S., \& Singh, D. (2008). The emergence of hierarchy in customer perceived value for services: A grounded analysis. Journal of American Academy of Business, 13, 65-71.

32. Skogland, I., \& Siguaw, J. A. (2004). Are your satisfied customers loyal? Cornell Hotel and Restaurant Administration Quarterly, 45, 221-234.

33. Lovelock, C. H., Patterson, P. G., \& Walker, R. H. (2001). Services marketing: An Asia- Pacific perspective (2th ed.). NSW: Prentice Hall.

34. Ekinci, Y., Massey, G. R., \& Dawes, P. L. (2008). An extended model of the antecedents and consequences of consumer satisfaction for hospitality services. European Journal of Marketing, 42, 35-68.

35. Sinha, I., \& DeSarbo, W. S. (1998). An integrated approach toward the spatial modeling of perceived customer value. Journal of Marketing Research, 35(2), 236-249.

36. Gale, B. T. (1994). Managing customer value: Creating quality \& service that customers can see. New York: The Free Press.

37. Parasuraman, A., Zeithaml, V. A., \& Berry, L. L. (1994). Reassessment of expectations as a comparison standard in measuring service quality: Implications for further research. Journal of Marketing, 58(1), 111-124.

38. Zeithaml, V. A., Berry, L. L., \& Parasuraman, A. The behavioral consequences of service quality. Journal of Marketing, 60(2), 31-46. 1996

39. Zeithaml, V. A., Bitner, M. J., \& Gremler, D. D. (2006). Services marketing: Integrating customer focus across the firm (4 ed.). Boston: McGrawHill Irwin.

40. Oliver, R. L. (1999). Whence consumer loyalty? Journal of Marketing, 63, 33-44.

41. Ganesh, J., Arnold, M. J., \& Reynolds, K. E. (2000). Understanding the customer base of service providers: An examination of the differences between switchers and stayers. Journal of Marketing, 64(3), 65-87.

42. Harris, L. C., \& Goode, M. M. (2004). The four levels of loyalty and the pivotal role of trust: A study of online service dynamics. Journal of Retailing, 80(2), 139-158.

43. Chandrashekaran, M., Rotte, K., Tax, S. S., \& Grewal, R. (2007). Satisfaction strength and customer loyalty. Journal of Marketing Research, 44(1), 153-163. 